\title{
Molecular characterization of water soluble organic nitrogen in marine rainwater by ultra-high resolution electrospray ionization mass spectrometry
}

\author{
K. E. Altieri ${ }^{1}$, M. G. Hastings ${ }^{2}$, A. J. Peters ${ }^{3}$, and D. M. Sigman ${ }^{1}$ \\ ${ }^{1}$ Department of Geosciences, Princeton University, Princeton, NJ, USA \\ ${ }^{2}$ Department of Geological Sciences \& Environmental Change Initiative, Brown University, Providence, RI, USA \\ ${ }^{3}$ Bermuda Institute of Ocean Sciences, St. Georges, Bermuda \\ Correspondence to: K. E. Altieri (kaltieri@ princeton.edu)
}

Received: 4 November 2011 - Published in Atmos. Chem. Phys. Discuss.: 29 November 2011

Revised: 22 March 2012 - Accepted: 1 April 2012 - Published: 12 April 2012

\begin{abstract}
Atmospheric water soluble organic nitrogen (WSON) is a subset of the complex organic matter in aerosols and rainwater, which impacts cloud condensation processes and aerosol chemical and optical properties and may play a significant role in the biogeochemical cycle of N. However, its sources, composition, connections to inorganic N, and variability are largely unknown. Rainwater samples were collected on the island of Bermuda $\left(32.27^{\circ} \mathrm{N}\right.$, $64.87^{\circ} \mathrm{W}$ ), which experiences both anthropogenic and marine influenced air masses. Samples were analyzed by ultrahigh resolution electrospray ionization Fourier transform ion cyclotron resonance mass spectrometry to chemically characterize the WSON. Elemental compositions of $2281 \mathrm{~N}$ containing compounds were determined over the mass range $\mathrm{m} / \mathrm{z}^{+} 50$ to 500. The five compound classes with the largest number of elemental formulas identified, in order from the highest number of formulas to the lowest, contained carbon, hydrogen, oxygen, and nitrogen ( $\mathrm{CHON}+), \mathrm{CHON}$ compounds that contained sulfur (CHONS+), $\mathrm{CHON}$ compounds that contained phosphorus (CHONP+), $\mathrm{CHON}$ compounds that contained both sulfur and phosphorus (CHONSP+), and compounds that contained only carbon, hydrogen, and nitrogen $(\mathrm{CHN}+)$. Compared to rainwater collected in the continental USA, average O:C ratios of all $\mathrm{N}$ containing compound classes were lower in the marine samples whereas double bond equivalent values were higher, suggesting a reduced role of secondary formation mechanisms. Despite their prevalence in continental rainwater, no organonitrates or nitrooxy-organosulfates were detected, but there was an
\end{abstract}

increased presence of organic S and organic P containing compounds in the marine rainwater. Cluster analysis showed a clear chemical distinction between samples collected during the cold season (October to March) which have anthropogenic air mass origins and samples collected during the warm season (April to September) with remote marine air mass origins. This, in conjunction with patterns identified in van Krevelen diagrams, suggests that the cold season WSON is a mixture of organic matter with both marine and anthropogenic sources while in the warm season the WSON appears to be dominated by marine sources. These findings indicate that, although the concentrations and percent contribution of WSON to total $\mathrm{N}$ is fairly consistent across diverse geographic regions, the chemical composition of WSON varies strongly as a function of source region and atmospheric environment.

\section{Introduction}

The global nitrogen $(\mathrm{N})$ cycle has been greatly perturbed by anthropogenic activities since the industrial revolution. The emission (and subsequent deposition) of anthropogenic reactive $\mathrm{N}$ (e.g., nitrate, ammonium, organic $\mathrm{N}$ ) has increased by a factor of ten since preindustrial times (Galloway et al., 2004). The impacts of this increased anthropogenic reactive $\mathrm{N}$ deposition are well documented and include acidification and loss of biodiversity in forests, lakes and streams, eutrophication and hypoxia in coastal environments and the 
modification of biogeochemical cycles within these systems (Paerl et al., 1990; Peierls and Paerl, 1997; Vitousek et al., 1997; Paerl et al., 1999; Howarth et al., 2000; Paerl et al., 2002; Elser et al., 2009). Though the impacts of increased $\mathrm{N}$ inputs to terrestrial and coastal systems are frequently discussed, the implications of atmospheric deposition of anthropogenic $\mathrm{N}$ to the open ocean are still uncertain (Duce et al., 2008). During summer in the East China Sea, patches of water with elevated nitrate concentrations were ascribed to rainfall events based on detection of low salinity, low phosphorus and high $\mathrm{N}$ concentrations (Kodama et al., 2011). Kodama et al. (2011) estimate that the atmospheric $\mathrm{N}$ supply from rainfall in the study area was on the same order of magnitude as $\mathrm{N}_{2}$ fixation and the diffusive upward flux of $\mathrm{N}$ in summer. Even stronger evidence of the impact of $\mathrm{N}$ deposition on surface ocean biogeochemistry was reported in the Northwestern Pacific Ocean where changes in $\mathrm{N}^{*}\left(\mathrm{~N}^{*}=\mathrm{N}-\left(\mathrm{R}_{N: P}\right)^{*} \mathrm{P}\right.$; a measure of excess nitrogen relative to phosphorus in the ocean (Gruber and Sarmiento, 1997)) were highly correlated with changes in anthropogenic $\mathrm{N}$ deposition downwind of East Asia where nitrogen oxide $\left(\mathrm{NO}_{\mathrm{x}}\right)$ emissions have increased over $250 \%$ from the late 1980's until today (Kim et al., 2011).

The significance of modern $\mathrm{N}$ deposition to the ocean depends primarily on the source of the $\mathrm{N}$ as well as its bioavailability. If the $\mathrm{N}$ is from terrestrial sources then it represents a new, and if anthropogenic, potentially increasing input of $\mathrm{N}$ to the oceans, with major biogeochemical implications including potentially altering the nutrient limitation regime as suggested by Kim et al. (2011). If most atmospheric $\mathrm{N}$ deposition over the ocean originates from the ocean, then it is a refluxing within the marine environment, not a new source of $\mathrm{N}$ to the surface communities. In this case, there is less potential for future increases in ocean $\mathrm{N}$ deposition and less biogeochemical significance in any changes that do occur.

Organic nitrogen $(\mathrm{ON})$ plays an important role in both atmospheric chemistry and the global biogeochemical $\mathrm{N}$ cycle. Though the number of measurements is small, organic $\mathrm{N}$ appears to be a ubiquitous and significant component of both rainwater and aerosols (i.e., $20-80 \%$ of the total $\mathrm{N}$ ) in both the polluted (Zhang et al., 2008) and remote marine atmosphere (Cornell et al., 1995; Spokes et al., 2000; Cornell et al., 2001; Cornell et al., 2003; Mace et al., 2003b, c; Miyazaki et al., 2010). A wide variety of organic N compounds have been measured, or proposed to exist in the marine atmosphere. These include amino acids (Mopper and Zimmermann, 1987; Gorzelska et al., 1992; Wedyan and Preston, 2008; Mandalakis et al., 2010), methyl and ethyl substituted ammonium salts (Facchini et al., 2008a), urea (Cornell et al., 1998; Mace et al., 2003a, b, c), and amide containing particles that resemble marine proteinaceous material (Hawkins and Russell, 2010). The emission of ON species from the surface ocean is usually linked to periods of high biological activity in the surface ocean. One bubble bursting study in a high biological activity area resulted in primarily water insoluble organic matter (WIOM)(Facchini et al., 2008b), however, a bubble bursting study in the Sargasso Sea reported high enrichment factors for water soluble organics in all aerosol size fractions (Keene et al., 2007). In the North Pacific, ON concentrations were higher during periods of high biological activity, with ON/OC ratios increasing significantly over periods of low biological activity (Miyazaki et al., 2010). ON in aerosols from the Eastern Atlantic Ocean was linked to microbial and phytoplankton contributions using amino acid measurements (Wedyan 2008). Many of these compounds could be from the oxidation of insoluble primary organic material emitted by sea spray (Facchini et al., 2008b), and/or emissions of reduced biogenic gases (e.g., dimethylsulfide (DMS), ammonia $\left(\mathrm{NH}_{3}\right)$, dimethylamine (DMA), diethylamine (DEA)). However, these known species are a small fraction of the total ON which still lacks characterization at the molecular level.

Recent work on the role of ammonium and amines in secondary organic aerosol (SOA) production has demonstrated the potential for organic compounds with reduced $\mathrm{N}$ functionality to form in the atmosphere through a variety of reaction pathways. Alkylamines are involved in a number of atmospherically relevant reactions including neutralization and displacement of ammonium in ammonium sulfate, ammonium bisulfate, and ammonium nitrate salts creating aminium salts (Bzdek et al., 2010a, b; Qiu et al., 2011), and heterogeneous reactions with sulfuric acid creating alkylaminium sulfates (Wang et al., 2010). Substituted imidazoles form via aqueous reactions of glyoxal with amino acids (Haan et al., 2009) and aqueous reaction of glyoxal with ammonium sulfate (Yu et al., 2011). Imines, N-containing oligomers, and substituted imidazoles form during reactions of methylglyoxal with amino acids, ammonium sulfate, and methylamine (De Haan et al., 2011). N containing oligomers also form during reactions of isoprene photo-oxidation under high $\mathrm{NO}_{\mathrm{x}}$ conditions (Nguyen et al., 2011). Many of these N-containing organic compounds have light absorbing properties and effectively nucleate new particle formation. The likelihood of these reactions occurring in the remote marine atmosphere is unknown, as most studies are conducted to simulate anthropogenic environments. However, they provide a framework for understanding the types of formation pathways that could lead to secondary organic $\mathrm{N}$ compounds in the remote marine atmosphere via reactions of marine biogenic volatile organic compounds (VOCs) and ammonia/amines emitted from the surface ocean.

The Bermuda region of the Sargasso Sea (western subtropical North Atlantic) is well situated for addressing questions on the composition and sources of atmospheric organics in the marine environment. Its northern latitude and position in the western Atlantic $\left(32.27^{\circ} \mathrm{N}, 64.87^{\circ} \mathrm{W}\right)$ causes Bermuda to experience a diverse set of atmospheric conditions, with seasonal predictability. Several decades of time series observations have established that deposition at Bermuda and the surrounding ocean region are typically dominated by two air 

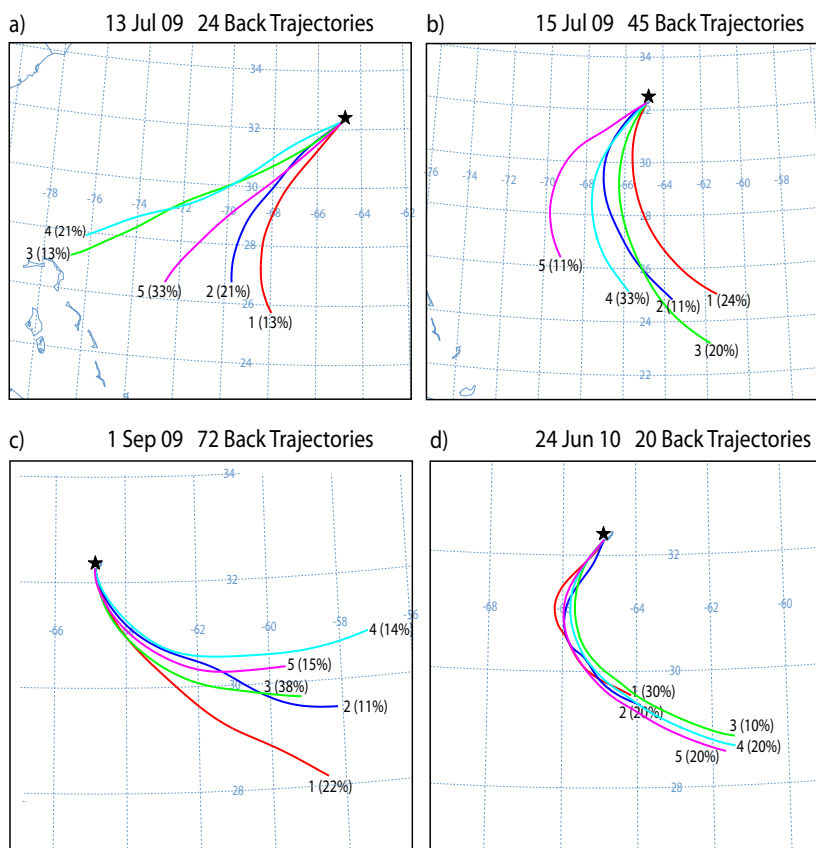

d)

24 Jun 1020 Back Trajectories

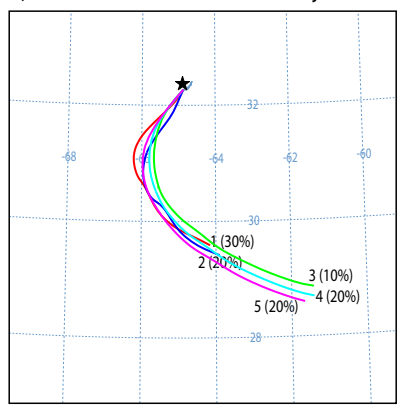

Fig. 1. (a-d) Warm season $36 \mathrm{~h}$ back trajectories clustered from $100 \mathrm{~m}, 2000 \mathrm{~m}$, and $5000 \mathrm{~m}$ starting every hour during the rain event for the four warm season events. The number of back trajectories clustered is therefore dependent on the length of the rain event. The trajectories are numbered 1-5 and labeled with the percentage of total trajectories (shown in each figure) represented in that mean trajectory. The starting location for the back trajectories is the island of Bermuda $32.27^{\circ} \mathrm{N} 64.87^{\circ} \mathrm{W}$ (black star).

mass regimes, a characteristic that has also proven useful in diagnosis of source signals (Moody, 1988, 1995) (Figs. 1, 2). During the cool season (October to March), rapid transport frequently occurs from eastern North America to Bermuda (Fig. 2). During the warm season (April to September), the Bermuda high decreases outflow from the continent, causing slower moving marine air masses to arrive at Bermuda from the south, southeast, and southwest (Moody, 1988) (Fig. 1). It has been shown previously that during the cold season, North American influenced air masses deposit high sulfate and total acidity in wet deposition at Bermuda (Galloway et al., 1982; Jickells et al., 1982). Interestingly, while sulfate concentrations and other anthropogenic tracers are much lower in concentration during the warm season, an equivalent amount of nitrate is deposited at Bermuda during the warm and cold seasons, despite the apparent lack of anthropogenic influence on warm season air masses (Moody, 1988; Hastings et al., 2003). The stable isotopes of nitrate and total N show clear seasonal variations (Hastings et al., 2003; Knapp et al., 2010) providing insights into this discrepancy, but questions remain as to the sources of nitrate, ammonium, and organic $\mathrm{N}$ in warm season precipitation at Bermuda. This seasonal dichotomy facilitates a comparison of the compo-

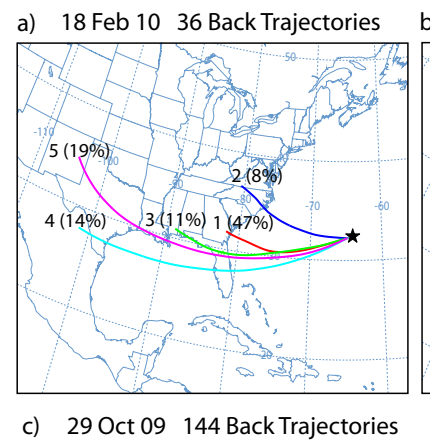

b) 8 Oct 09144 Back Trajectories
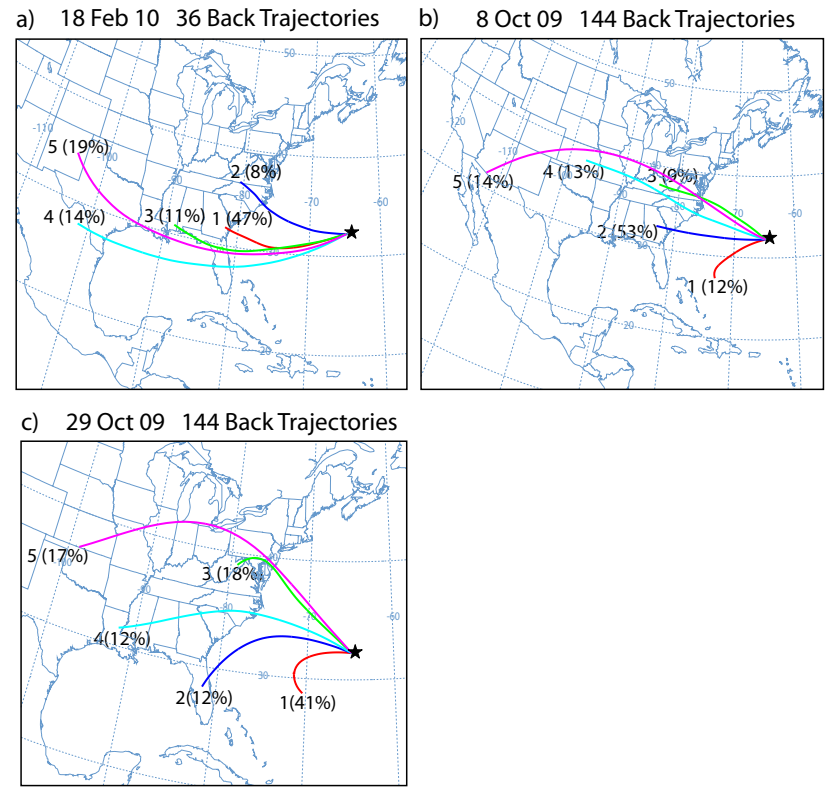

$$
\text { s. }
$$

Fig. 2. (a-c). Cold season $36 \mathrm{~h}$ back trajectories for the three cold season rain events clustered from $100 \mathrm{~m}, 2000 \mathrm{~m}$, and $5000 \mathrm{~m}$ starting every hour during the rain event as in Fig. 1.

sition of $\mathrm{N}$ deposition impacted by anthropogenic activities versus that from marine-influenced air masses.

In this work, we use ultra-high resolution mass spectrometry to characterize the composition of WSON in marine rainwater analogous to the characterization of continental rainwater in (Altieri et al., 2009a, b). The goal of this study is to determine how many compounds make up this complex mixture, to identify the $\mathrm{N}$ functionality (reduced or oxidized), to link groups of compounds to anthropogenic or biogenic/marine sources, and to distinguish signs of secondary processing in the marine atmosphere and the contribution of primary marine emissions.

\section{Methods}

\subsection{Sample collection}

Rainwater samples have been collected on the island of Bermuda $\left(32.27^{\circ} \mathrm{N}, 64.87^{\circ} \mathrm{W}\right)$ since July of 2009 at an active ambient air quality monitoring site (station Prospect). Ambient air quality at this location is typically very good and characterized by low levels of $\mathrm{NO}_{\mathrm{x}}$, sulfur dioxide $\left(\mathrm{SO}_{2}\right)$, and particulate matter (TSP, $\mathrm{PM}_{10}$, and $\mathrm{PM}_{2.5}$; Andrew Peters, unpublished data). The site is located atop a water catchment $65 \mathrm{~m}$ above sea level. It is unobstructed in all directions and is the second highest point on the island. Rainwater samples were collected in acid washed polyethylene buckets using an automatic rain collector (Aerochem Metrics model 301). Samples were collected on an event basis and retrieved daily to limit microbial degradation of organic 
matter and consumption of inorganic nutrients. For all samples, the $\mathrm{pH}$, rain volume, and conductivity are measured before being stored at $-20^{\circ} \mathrm{C}$. Freezing at $-20^{\circ} \mathrm{C}$ is sufficient to preserve the concentration and isotopic composition of nitrate $\left(\mathrm{NO}_{3}^{-}\right)$and total $\mathrm{N}$ and to preserve the chemical composition of rainwater samples analyzed by electrospray ionization-mass spectrometry (ESI-MS) (Hastings et al., 2003; Seitzinger et al., 2003; Knapp et al., 2005, 2010). Field blanks were collected once per month by placing 200 $\mathrm{mL}$ of deionized water into the rainwater collector overnight and then collecting the water in the same way as a rainwater sample. The full suite of chemical analyses was also performed on the field blanks to assess possible contamination from the collector or from sample handling.

\subsection{Nutrient Concentrations}

Bulk inorganic $\mathrm{N}$ concentrations of nitrate plus nitrite, and ammonium $\left(\mathrm{NO}_{3}^{-}+\mathrm{NO}_{2}^{-}, \mathrm{NH}_{4}^{+}\right)$were determined with an automated nutrient analyzer and standard colorimetric methods (Lachat, Inc). Total dissolved N (TDN) was measured with an Antek 7000 TN Analyzer (Altieri et al., 2009b). Water soluble organic N (WSON) was determined as the difference between TDN and DIN (Eq. 1).

$$
\mathrm{WSON}=\mathrm{TDN}-\left(\mathrm{NO}_{3}^{-}+\mathrm{NO}_{2}^{-}+\mathrm{NH}_{4}^{+}\right)
$$

Calibrations were performed using urea and nitrate standards for TDN and DIN, respectively. Field and bottle blanks treated as samples had $0.1 \mu \mathrm{M} \mathrm{NH}+, 0.1 \mu \mathrm{M} \mathrm{NO}_{3}^{-}+\mathrm{NO}_{2}^{-}$, $0 \mu \mathrm{M}$ TDN,$-0.1 \mu \mathrm{M}$ WSON. Ion chromatography was used to quantify sulfate and sodium (not all data shown). Nonsea-salt sulfate concentrations are calculated using equation 2 with species in $\mu$ eq $\mathrm{L}^{-1}$ (Keene et al., 1986):

$\mathrm{nssSO}_{4}^{2-}=\left[\mathrm{SO}_{4}^{2-}\right]-0.1555 *\left[\mathrm{Na}^{+}\right]$

\subsection{Air mass back trajectory}

To determine the source regions, air mass back trajectories were computed for all sample days using NOAA's Hybrid Single-Particle Lagrangian Integrated Trajectory model (HYSPLIT v 4) with NCEP Global Data Assimilation System (GDAS) output. HYSPLIT is used to compute the trajectory of a suspended particle backward in time from a specified point, in this case the island of Bermuda, using a simple particle dispersion simulation and meteorological data. It is accessed via the NOAA ARL READY website at http://www.arl.noaa.gov/ready/hysplit4.html (NOAA Air Resources Laboratory, Silver Spring, Maryland). Threedimensional trajectories were determined at three altitudes: $100 \mathrm{~m}, 2000 \mathrm{~m}$, and $5000 \mathrm{~m}$. Sensitivity tests to changes in initial conditions indicated that the main sources of uncertainty in the final trajectory were the starting time and the altitude, hence the use of multiple altitudes for each back trajectory. To deal with the variability associated with starting time, trajectories were run starting every hour during the rain event. The duration of the rain event was determined by cross-referencing sample collection dates with the meteorological observation archive on the Bermuda National Weather Service website (www.weather.bm). Five mean trajectories were extracted from the multiple trajectories associated with a single rain event through HYSPLIT's clustering algorithm. HYSPLIT calculates the mean trajectory by averaging over all of the input trajectories at every hour.

\subsection{FT-ICR MS}

Analyses were performed on the rainwater samples with a 7-T electrospray ionization (ESI) Fourier transform ion cyclotron resonance mass spectrometer (FT-ICR MS) (ThermoFinnigan LTQ-XL, Woods Hole Oceanographic Institution Fourier Transform Mass Spectrometry Facility) operated in the positive ion mode. The FT-ICR MS scans were acquired as individual transients which were processed using customwritten MATLAB code provided by Southam et al. (2007). For each sample, the individual transient files were averaged if their total ion current (TIC) was above $20 \%$ of the maximum TIC for each set of transients collected. The transients were averaged, Hanning apodized, zero-filled once, fast Fourier-transformed, and calibrated using the customwritten MATLAB code. A peak was required to have a signal-to-noise ratio greater than 10 , and the peak lists were internally calibrated. The calibrants were corrected from neutral masses assuming the addition of hydrogen in positive ion mode. The individual sample peak lists were aligned using MATLAB code provided by Mantini et al. (2007). The alignment code creates a single master list of the peaks $(\mathrm{m} / \mathrm{z}$ values) present in all the samples, where peaks within an error of $1 \mathrm{ppm}$ are considered to be the same. There were $14924 \mathrm{~m} / \mathrm{z}$ 's detected across the seven rainwater samples (Supplement Fig. S1).

The samples were diluted with methanol 50:50 v/v, with $0.05 \%$ formic acid added immediately before injection to limit solvent interaction, and then introduced into the ESI source by direct infusion at a flow rate of $4-5 \mu \mathrm{L} \mathrm{min}{ }^{-1}$. According to Bateman et al. (2008), this is not sufficiently long enough for the solvent to interact with the sample. For the positive ion mode, the needle voltage was $4 \mathrm{kV}$, the capillary voltage was $20 \mathrm{~V}$, the capillary temperature was $260^{\circ} \mathrm{C}$, and the tube lens was $80 \mathrm{~V}$.

Elemental formulas were assigned to the aligned peaks $(\mathrm{m} / \mathrm{z}$ values) using the Compound Identification Algorithm (CIA), described by Kujawinski and Behn (2006) and modified in Kujawinski et al. (2009). Before calculating the elemental formulas, the measured $\mathrm{m} / \mathrm{z}$ values were converted to neutral masses assuming addition of a sodium or hydrogen in the positive ion mode data; the mass of the electron was also considered. In the CIA, the following parameters were set: (a) formula error was $1 \mathrm{ppm}$, (b) the 
Table 1. Bulk properties of rainwater samples.

\begin{tabular}{ccccc}
\hline Date Collected & Rain Amt $(\mathrm{mm})$ & $\mathrm{NO}_{3}^{-}(\mu \mathrm{M})$ & $\mathrm{NH}_{4}^{+}(\mu \mathrm{M})$ & WSON $(\mu \mathrm{M})$ \\
\hline 13 Jul 2009 & 14.48 & 7.9 & 4.2 & 2.0 \\
15 Jul 2009 & 15.24 & 5.3 & 1.5 & 1.6 \\
1 Sep 2009 & 5.72 & 11.9 & 4.1 & 2.8 \\
8 Oct 2009 & $<5$ & 13.0 & 5.7 & 2.8 \\
29 Oct 2009 & $<5$ & 13.3 & 16.2 & 4.2 \\
18 Feb 2010 & 9.4 & 7.2 & 7.6 & 1.7 \\
24 Jun 2010 & 13.72 & 6.4 & 8.7 & \\
\hline
\end{tabular}

relationship error was $20 \mathrm{ppm}$, and (c) the mass limit above which elemental formulas were assigned by functional group relationships only was $500 \mathrm{Da}$. For this study, elemental formulas were determined for $\mathrm{m} / \mathrm{z}$, values below $500 \mathrm{Da}$ with an in-house database of mathematically and chemically legitimate formulae within the $1 \mathrm{ppm}$ error window. When there were multiple legitimate formulae within a $1 \mathrm{ppm}$ error window, the 'best' formula was chosen based on the following steps:

1. count the number of $\mathrm{N}, \mathrm{S}$, and $\mathrm{P}$ in the elemental formulas and choose the formula with the lowest sum of $\mathrm{N}$ $+\mathrm{S}+\mathrm{P}$; if there are multiple formulas with the same, lowest, sum of $\mathrm{N}+\mathrm{S}+\mathrm{P}$, only consider formulas with $\mathrm{P} \leq 1$ or $\mathrm{S} \leq 3$.

2. From this list, select the formula with the lowest error

Note that these steps have been tested against synthetic data as described by Kujawinski and Behn (2006) and result in the highest percent of correct elemental formulas. The formula finding algorithm does consider functional group relationships in assigning elemental formulas; and, the functional group relationships used by CIA are common to refractory dissolved organic matter (e.g., humic acids) as well as to atmospheric organic matter (e.g., $\mathrm{CH}_{2}, \mathrm{CH}_{4}-\mathrm{O}, \mathrm{C}_{2} \mathrm{H}_{4} \mathrm{O}, \mathrm{NH}$, $\mathrm{OH}, \mathrm{C}_{2} \mathrm{H}_{2} \mathrm{O}$; see Table 1 in Kujawinski and Behn, 2006). Isotopomers with a ${ }^{13} \mathrm{C}$ atom are identified in the next step of $\mathrm{CIA}$, and elemental formulas are corrected to reflect ${ }^{13} \mathrm{C}$ content. Boundary values for molecular elemental ratios were applied as a filtering tool (Koch et al., 2005). The O:C, H:C, and $\mathrm{N}$ : $\mathrm{C}$ ratios were limited to $<5, \geq 0.3$, and $<1$, respectively. The "N rule" was also applied to elemental formulas whereby neutral molecules containing an odd number of ${ }^{14} \mathrm{~N}$ atoms must always exhibit an odd nominal mass, and conversely neutral molecules containing an even number of ${ }^{14} \mathrm{~N}$ atoms always exhibit an even mass as ${ }^{14} \mathrm{~N}$ has an odd number of valences and an even mass (Koch et al., 2005). In some instances two formulas were possible for one $\mathrm{m} / \mathrm{z}$, one with a $\mathrm{Na}^{+}$and one with $\mathrm{H}^{+}$. In this case the Kendrick mass defect was calculated (Hughey et al., 2001) and the longest homologous series of the simplest formula was retained. This, in addition to the use of ${ }^{13} \mathrm{C}$ peaks as confirmation, allowed the assignment of one formula per $\mathrm{m} / \mathrm{z}$. Ions were also characterized by the double bond equivalents (DBE; i.e., number of rings plus double bonds), calculated from Eq. (3) (McLafferty, 1993):

$\mathrm{DBE}=c-\frac{1}{2} h+\frac{1}{2}(n+p)+1$ for elemental composition, $\mathrm{C}_{c} \mathrm{H}_{h} \mathrm{O}_{o} \mathrm{~N}_{n} \mathrm{P}_{p} \mathrm{~S}_{s}$

The DBE must be a non-negative integer for chemically legitimate elemental formulas. Masses detected in the solvent blank were subtracted from all samples before analysis. There were 4574 elemental formulas assigned, with 2281 containing at least one $\mathrm{N}$ atom. A table of the $\mathrm{m} / \mathrm{z}$ 's of all $\mathrm{N}$ containing compounds and their corresponding elemental formulas for the 1 September 2009 sample is available in the supplemental information (Table S1).

\subsection{Multivariate statistical comparisons}

Differences in $\mathrm{m} / \mathrm{z}$ peak lists among the samples were assessed with cluster analysis (Koch et al., 2005; Kujawinski et al., 2009). The peak heights were transformed to presence (peak height $=1$ ) or absence (peak height $=0$ ) to eliminate the influence of peak height which is a measure of not only an ion's concentration but also its ionization efficiency. Cluster analysis was performed on the data matrix using Bray-Curtis distance measures combined with Ward's linkage method. There was no chaining present. PC Ord v 5.4 was used for all multivariate comparisons.

\section{Results and discussion}

The seven rainwater samples analyzed by ESI FT-ICR MS are a subset chosen from 14 months of event-based sampling. The samples were chosen to be representative of warm and cold season air mass back trajectories. The inorganic $\mathrm{N}$ concentrations in these samples are typical for rainwater collected at Bermuda (Galloway et al., 1982; Hastings et al., 2003; Knapp et al., 2010) (Table 1). The WSON concentrations are consistent with concentrations reported in remote marine rainwater $(2-4 \mu \mathrm{M})$, as is the contribution of WSON to TDN (10-19\%, Table 1) (Cornell et al., 1995, 2001, 2003; Mace et al., 2003a, b, c). 
Table 2. Number of compounds in each compound class and the average (arithmetic mean) elemental ratios for each compound class in all 7 marine rainwaters (compounds that do not contain $\mathrm{N}$ in their elemental formula are not included). The average molecular weight is denoted by "MW" and the average double bond equivalents by "DBE" as in the text.

\begin{tabular}{lcccccccc}
\hline Class & Number & O:C & H:C & N:C & O:N & MW & OM:OC & DBE \\
\hline CHON+ & 1539 & 0.34 & 1.60 & 0.29 & 2.18 & 314 & 1.92 & 6.14 \\
CHONS+ & 522 & 0.39 & 1.56 & 0.37 & 1.56 & 318 & 2.50 & 5.29 \\
CHONP+ & 48 & 0.40 & 0.99 & 0.37 & 1.45 & 329 & 2.54 & 9.35 \\
CHONSP+ & 89 & 0.42 & 0.68 & 0.35 & 1.80 & 354 & 3.01 & 10.57 \\
CHN+ & 83 & - & 1.54 & 0.28 & - & 250 & 1.46 & 6.53 \\
\hline
\end{tabular}

\subsection{Marine rainwater WSON composition}

In this section, to compare the WSON in marine rainwater with previously published work on rainwater WSON collected in the continental USA (Altieri et al., 2009b), we analyze the rainwater samples as one group representative of marine rainwater in the same manner that continental rainwater was treated. For example, the elemental formulas are first grouped into compound class (e.g., $\mathrm{CHON}+, \mathrm{CHONS}+$ ), and then the number of compounds and average elemental ratios (e.g., O:C, N:C, H:C, DBE) are compared across compound classes in the marine rainwater and compared to continental rainwater. Changes in elemental ratios can be indicative of atmospheric reactions, for example, O:C ratios increase throughout the day from SOA formation associated with photochemistry (Volkamer et al., 2006; Aiken et al., 2008). There were $2281 \mathrm{~N}$ containing elemental formulas detected in the seven rainwater samples. This is an underestimate of the actual number of $\mathrm{N}$ containing compounds because for each elemental composition there are multiple structural isomers possible, with the number of isomers increasing as molecular weight increases. The compound class containing carbon, hydrogen, oxygen and nitrogen $(\mathrm{CHON}+)$ has the largest number of formulas in the marine rainwater, as it did in continental rainwater samples (Altieri et al., 2009b). However, it is less dominant in the marine rain than in the continental rain, representing $67 \%$ of the total $\mathrm{N}$ containing formulas as opposed to $87 \%$ (Table 2, Supplement Figs. S2, S3).

The number of $\mathrm{CHN}+$ compounds in the marine rainwater is only slightly higher than in the continental rainwater, $4 \%$ and $2 \%$ respectively (Table 2, Supplement Figs. S2, S3). However, there is no overlap in the $\mathrm{CHN}+$ elemental formulas detected in the continental rainwater $\mathrm{CHN}+$ class with those detected in the marine rainwater $\mathrm{CHN}+$. The average DBE and $\mathrm{N}: \mathrm{C}(6.53,0.28$, respectively) are higher than in the continental rainwater $\mathrm{CHN}+(4,0.22$, respectively) (Table 2). In the continental rainwater these compounds were assumed to be from anthropogenic and/or biomass burning sources. It is possible in the marine system these are refractory ON compounds released from the surface ocean that have yet to be degraded by atmospheric processes, but it is more likely that there is long range transport of biomass burning species. The molecular formula corresponding to levoglucosan $\left(\mathrm{m} / \mathrm{z}^{+}\right.$185.042018), a biomass burning tracer, is present in all of the marine rainwater samples. The DBE and $\mathrm{N}: \mathrm{C}$ values are consistent with organic $\mathrm{N}$ containing biomass burning compounds, and there are three $\mathrm{CHN}-\mathrm{H}^{+}$ compounds in the marine rainwater which are components of the dominant Kendrick mass series of $\mathrm{CHN}-\mathrm{H}^{+}$molecules found in all biomass burning samples analyzed by Laskin et al. (2009) (i.e., $\mathrm{C}_{3} \mathrm{H}_{4} \mathrm{~N}_{2}, \mathrm{C}_{7} \mathrm{H}_{12} \mathrm{~N}_{2}, \mathrm{C}_{8} \mathrm{H}_{14} \mathrm{~N}_{2}$ ). Further analysis would be needed to verify the structure of these compounds which would enable a more detailed discussion of their likely sources.

An important difference to highlight between the marine and continental rainwater is the lack of CHON-, CHONS, and CHOS- compound classes detected in the negative ionization mode in the marine rainwater. These groups were identified as organonitrates, nitrooxy-organosulfates, and organosulfates in continental rainwater, known contributors to SOA formed under anthropogenic conditions (i.e., high $\left[\mathrm{NO}_{\mathrm{x}}\right]$ and acidic sulfate seed aerosol) (Surratt et al., 2007; Gomez-Gonzalez et al., 2008; Surratt et al., 2008). The lack of these compounds in marine rainwater suggests that their lifetime is not long enough for transport from the continental USA to the remote marine atmosphere of Bermuda, $\sim 1000 \mathrm{~km}$ off shore. There is also no apparent in situ formation in the marine atmosphere upwind of, or near Bermuda, despite the fact that average nss-sulfate concentrations in Bermuda rainwater vary from $6 \mu \mathrm{M}$ in the warm season to $32 \mu \mathrm{M}$ in the cold season (data not shown). The warm and cold season volume weighted average nitrate concentrations in Bermuda are 5 and $6.4 \mu \mathrm{M}$, respectively, so despite a regime shift from warm season nss-sulfate/nitrate ratios of $\leq 1$ to cold season ratios $\gg$ than 1 , there is no apparent organosulfate or nitrooxy-organosulfate formation. Organosulfate compounds were detected in aerosol samples collected at Amsterdam Island during times of high biological activity with nss-sulfate/nitrate ratios of $\sim 15$ (Claeys et al., 2010), and in the Southeast Pacific when sulfate and organic concentrations were at a maximum and ammonium concentrations were at a minimum (Hawkins et al., 2010). The oligotrophic nature of the Sargasso Sea might be limiting the biological emission of the precursor species necessary 


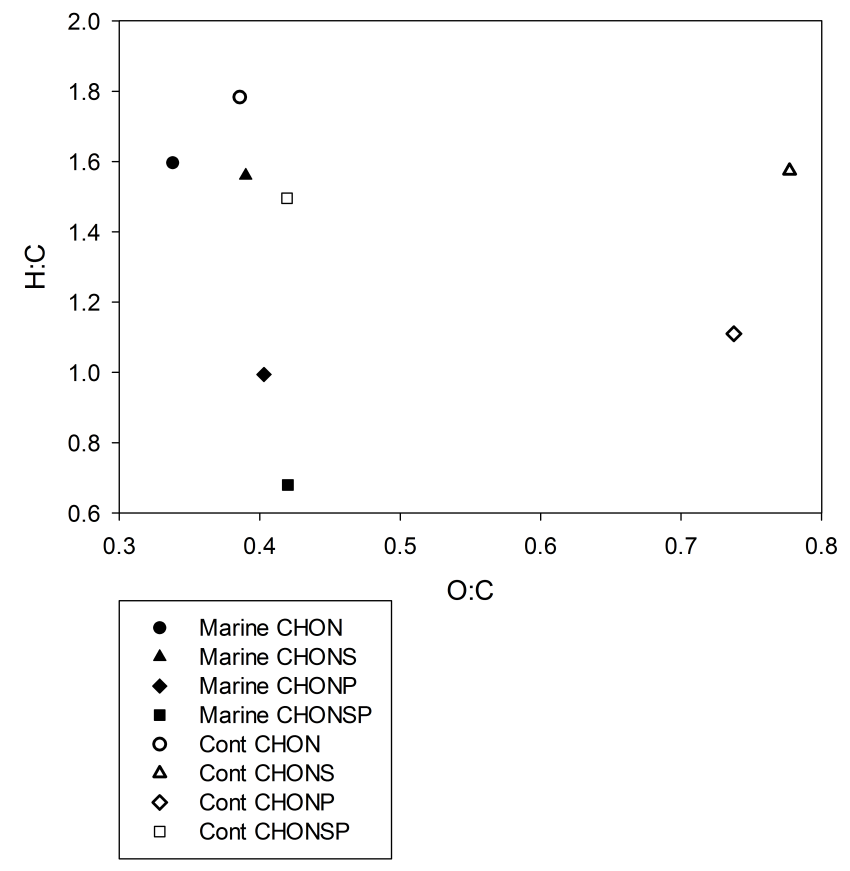

Fig. 3. van Krevelen diagram of the average elemental ratios of $\mathrm{N}$ containing compound classes in combined marine rainwater samples and previously published continental rainwater (Altieri et al., 2009b).

to form marine derived organosulfates. Sampling targeted to coincide with the spring bloom in the subtropical North Atlantic would resolve this discrepancy.

The average elemental ratios of the $\mathrm{N}$ containing compound classes in the marine rainwater are comparable in $\mathrm{H}: \mathrm{C}$ ratios with the continental rainwater but consistently lower in O:C ratios (Fig. 3, Table 2). For example, the CHON+ class in marine rainwater has an average $\mathrm{O}: \mathrm{C}$ of 0.34 whereas the $\mathrm{CHON}+$ class in continental rainwater has an average $\mathrm{O}: \mathrm{C}$ of 0.39 (Fig. 3, filled black circle and open black circle, respectively). The average O:C ratios of the $\mathrm{N}$ containing compound classes are also lower when plotted as a function of $\mathrm{N}: \mathrm{C}$ ratios (Fig. 4). The continental rainwater has a larger range of $\mathrm{N}: \mathrm{C}$ than the marine rainwater $(0.16-0.59$ and 0.28-0.37, respectively; Fig. 4). However, it is important to note that the range in $\mathrm{N}: \mathrm{C}$ values in the continental rainwater is driven by changes in the carbon content, not the $\mathrm{N}$ content of the molecules. The O:C ratios in the continental rainwater are consistent with anthropogenic emissions leading to increased secondary formation, and thus higher O:C. This chemistry is consistent with higher $\mathrm{NO}_{\mathrm{x}}$ concentrations producing more water soluble carbonyls and thus more secondary formation via aqueous reactions in the anthropogenic environment (Ervens and Volkamer, 2010). This interpretation is also supported by the DBE (i.e., \# of rings + \# of double bonds; see Eq. (3)) values, which range from 2.3-6 in the continental rainwater and 5-10.6 in the marine rain-

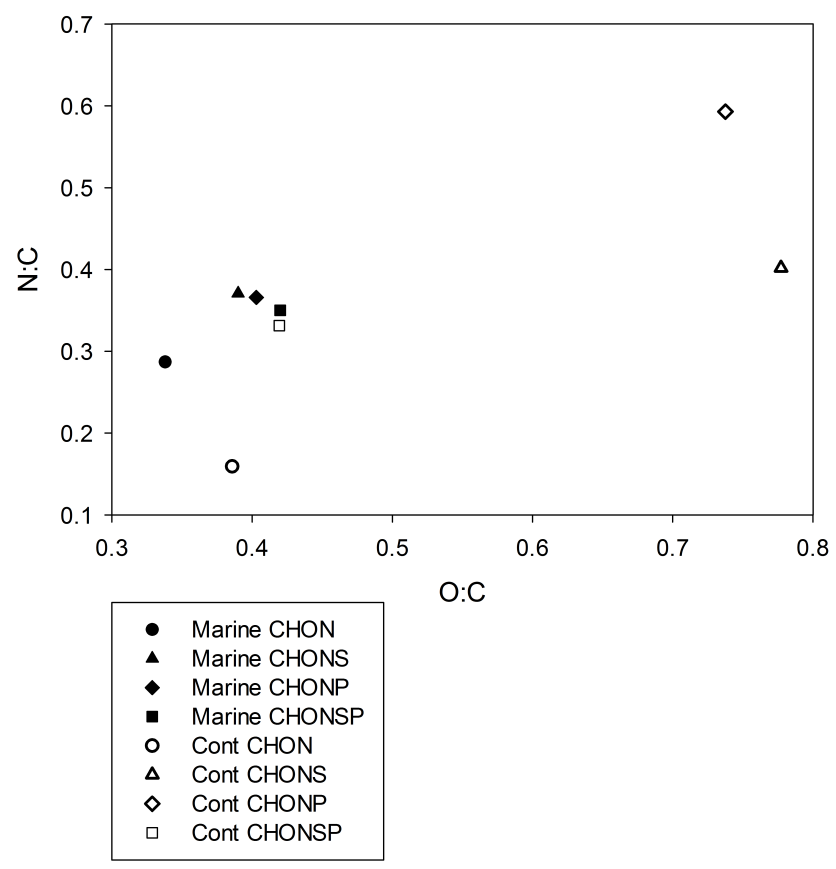

Fig. 4. $\mathrm{N}$ focused van Krevelen diagram of average elemental ratios of $\mathrm{N}$ containing compound classes in combined marine rainwater samples and previously published continental rainwater (Altieri et al., 2009b).

water (Table 2). The higher average DBE of marine rainwater is consistent with their containing more primary organic nitrogen that has not undergone secondary formation mechanisms, which tend to lower DBE values and increase O:C values (Table 2, Supplement Fig. S4) (Bateman et al., 2011).

\subsubsection{CHON+ and amino acids}

There are $1539 \mathrm{CHON}+$ elemental formulas, the second largest compound class after compounds containing $\mathrm{CHO}+$ only, and the highest $\mathrm{N}$ containing compound class by $\sim 1000$ elemental formulas. Of the $1539 \mathrm{CHON}+$ compounds, 512 contain one $\mathrm{N}$ atom, 280 contain two $\mathrm{N}$ atoms, 136 contain three $\mathrm{N}$ atoms, 185 contain four $\mathrm{N}$ atoms, with 426 having greater than four $\mathrm{N}$ atoms. In the continental rainwater, 201 of the $281 \mathrm{CHON}+$ compounds contained only one $\mathrm{N}$ atom; however, the mass range scanned was smaller $\left(\mathrm{m} / \mathrm{z}^{+} 50\right.$ 300 ), possibly precluding the detection of compounds with multiple $\mathrm{N}$ atoms. In the continental rainwater, the $\mathrm{CHON+}$ class had the lowest $\mathrm{O}: \mathrm{C}$, total organic mass to organic carbon mass (OM:OC), and highest $\mathrm{O}: \mathrm{N}$ ratios than all of the other oxygen containing classes, and this is also true for the $\mathrm{CHON}+$ in marine rainwater. Consistent with the elemental ratio discussion above, when comparing the two $\mathrm{CHON}+$ classes, the marine $\mathrm{CHON}+$ has higher average $\mathrm{N}: \mathrm{C}$ ratios (0.29) and DBE (6.14), but lower average O:N (2.18) and $\mathrm{O}: \mathrm{C}(0.34)$ ratios than the continental $\mathrm{CHON}+(\mathrm{N}: \mathrm{C}=0.16$, $\mathrm{DBE}=2.81, \mathrm{O}: \mathrm{N}=3.07, \mathrm{O}: \mathrm{C}=0.39$; Table 2). 
Amino acids are commonly quantified in rainwater (Gorzelska et al., 1992), fog water (McGregor and Anastasio, 2001), and aerosols (Zhang et al., 2002) and can range from $2-25 \%$ of total WSON. There were nine CHON+ elemental formulas in the marine rainwater that are consistent with amino acids commonly measured in rainwater as bulk dissolved free amino acids: glutamate, arginine, phenylalanine, tyrosine, lysine, threonine, asparagine, glutamine, and proline. Methionine, a sulfur containing amino acid was present in the CHONS+ compound class. There were eight amino acids identified in continental rainwater, five of which were also present in the marine rainwater (Altieri et al., 2009b). There are $455 \mathrm{CHON}+$ compounds with one $\mathrm{N}$ and at least two $\mathrm{O}$ atoms present on the molecule. This composition is typical for amino acids but the molecular weight of these molecules are higher than those of known amino acids, up to $470 \mathrm{Da}$. The oxygen content varies from 2-13 O atoms and the average DBE is 4.8. Amino acids are a frequently measured component of WSON, are highly reactive, can be oxidized in the atmosphere, and can act as catalysts in condensed phase reactions (Nozière and Córdova, 2008). It is possible that the decomposition of protein and pollen could contribute to the reduced $\mathrm{N}$ fraction of WSON, and specifically the amino acids and the amino acid like compounds. It is also well documented that atmospheric condensed phase (e.g., aerosol phase and in-cloud) reactions lead to complex product formation including oligomers; therefore, it is possible that condensed phase reactions of amino acids in the marine atmosphere would lead to the formation of many compounds that would not be quantifiable by traditional techniques used to measure amino acids. One way to identify these series of related compounds is the Kendrick mass defect (KMD). Compounds with the same KMD have the same number and type of heteroatoms and DBE but differ in the number of $\mathrm{CH}_{2}$ groups (Hughey et al., 2001). Of all the $\mathrm{N}$ containing compounds, $49 \%$ of the masses were in a Kendrick series ranging from 3-19 formulas. The longest homologous series was in the $\mathrm{N}_{1} \mathrm{O}_{5}$ family which went from $\mathrm{C}_{5} \mathrm{H}_{7} \mathrm{O}_{5} \mathrm{~N}_{1}$ to $\mathrm{C}_{23} \mathrm{H}_{43} \mathrm{O}_{5} \mathrm{~N}_{1}$. When the Kendrick mass defect is plotted as a function of the nominal Kendrick mass these series of compounds fall on a horizontal line separated by $14 \mathrm{Da}$ (Supplement Fig. S5). This makes identifying compounds of different classes visually easier as they are displaced vertically. The contribution of amino acids to total WSON may only range from $2-25 \%$, but since the $\mathrm{CHON}+$ compound class dominates in number, and there are regular patterns in mass differences it is likely that there are numerous reaction products and thus their quantitative contribution to WSON could be much higher.

In the continental rainwater, the presence of compounds with one $\mathrm{N}$ atom in combination with the presence of negative ion CHON- and CHONS- compounds suggested that the $\mathrm{N}$ is incorporated via organic reactions with inorganic $\mathrm{NO}_{\mathrm{x}}$ (as in the organonitrates), or ammonium salts (e.g., ammonium sulfate, ammonium nitrate) leading to the secondary formation of ON containing molecules (Altieri et al., 2009a, b). In the continental rainwater, the complexity and patterns evident in the van Krevelen diagrams occur because of reactions with the carbon and oxygen content of the molecule, leaving the $\mathrm{N}$ bonds untouched and contributing to the differences in average elemental ratios between the marine and continental rains. In contrast, the marine rainwater has a much larger contribution from compounds with multiple $\mathrm{N}$ and mixed heteroatoms (i.e., $\mathrm{S}$ and $\mathrm{P}$ as discussed below), which suggests that the $\mathrm{N}$ on these molecules is on the organic precursor and not added via reaction with inorganic $\mathrm{N}$. The high DBE values also suggest that the $\mathrm{N}$ (and S or P) is present in a ring structure or some other structurally protected mechanism. This could be verified using tandem MS/MS.

\subsubsection{Organic $P$ and $S$}

Elemental formulas containing $\mathrm{S}$ and $\mathrm{P}$ detected in the positive ion mode are more prevalent in the marine rainwater than in continental rainwater (Table 2, Supplement Figs. S2, S3). The increased number of CHONS+, CHONP+, and $\mathrm{CHONSP}+$ compounds in the marine rainwater could be due to an increased role of organic $\mathrm{S}$ and organic $\mathrm{P}$, either via reactions involving inorganic $\mathrm{S}$ and $\mathrm{P}$ that create organics, or a more prevalent role of primary $\mathrm{S}$ and $\mathrm{P}$ containing organics in the marine system. The CHONS+ and CHONP+ compound classes in the marine rainwater are comparable in $\mathrm{H}: \mathrm{C}$, lower in O:C, N:C, OM:OC, and higher in DBE than the continental CHONS+ and CHONP+ (Table 2; Altieri et al., 2009b). These properties suggest a more prevalent role of primary $\mathrm{S}$ and $\mathrm{P}$ containing organics in the marine rainwater. In contrast, the continental classes of CHONS+ and CHONP+, with higher $\mathrm{O}: \mathrm{C}$ and $\mathrm{OM}: \mathrm{OC}$ ratios and lower average DBE, are more likely to derive from secondary reactions involving inorganic S and P.

As discussed above, there were no organosulfate compounds detected in the marine rainwater, but there are a variety of other organosulfur compounds that likely contribute to the CHONS+, CHOPS+, and CHOS+ compound classes. The detection of the $\mathrm{S}$ containing compounds in the positive ion mode provides insight into the possible functionality of the $\mathrm{S}$ on the molecule. The thiol group plays an important role in amino acids, proteins, and enzyme co-factors (Vetter Russell et al., 1989) and as such would be a component of marine organic matter. Methionine was detected in the marine rainwater and could undergo secondary reactions to alter the $\mathrm{C}, \mathrm{O}$, and $\mathrm{N}$ content of the molecule but retain the thioether bond leading to a variety of CHONS+ compounds analogous to other known amino acid reactions discussed above. Methanesulfonic acid (MSA) is frequently the dominant organic compound in marine aerosol (Claeys et al., 2010) and plays a key role in the oceanic DMS cycle. Oxidative degradation of MSA (and other S containing components of the DMS cycle) likely leads to a variety of S 
containing organic products that would be present in marine rain and aerosols and detected as positive ions by FT-ICR MS.

There are few studies on atmospheric organic $\mathrm{P}$. Thus, it is difficult to infer the composition and sources of the $\mathrm{P}$ compounds present in the marine rainwater other than to attribute them to the organic $\mathrm{P}$ present in marine biomass and dissolved in the surface ocean dissolved organic P pool. The chemical composition of aerosol $\mathrm{P}$ was investigated using depth selective XAFS spectrometry, which showed that the $\mathrm{P}$ is present primarily as $\mathrm{P}^{5+}$, with minor contributions from $\mathrm{P}^{3+}$ (Tohno et al., 2001). This is not surprising since it is unlikely that atmospheric organic $\mathrm{P}$ compounds have an oxidation state of 0 to II. One of the few compositional studies on aerosol $\mathrm{P}$ in the marine environment was conducted by Graham and Duce (1979). They found that there were three main pools of reactive $\mathrm{P}$ : a predominantly orthophosphate group which was $25-30 \%$ of total P and likely from a crustal source, another $25-30 \%$ that was acid soluble and correlated with sodium, likely from a marine source and hypothesized to derive from marine bacteria, and a third group that was only soluble after high temperature oxidation, suggesting organic $\mathrm{P}$ that was highly condensed. The two $\mathrm{P}$ containing compound classes, CHONP+ and CHONSP+ have the two highest DBE values, 9.35 and 10.57 , respectively supporting the presence of highly condensed molecules.

\subsection{Cold season vs. warm season WSON characteristics}

The samples analyzed from the cold season (October to March) have expected cold season characteristics: their $36 \mathrm{~h}$ air mass back trajectories originate over the continental USA (Fig. 2), the volume weighted average nss-sulfate concentration is high $(9.7-16.9 \mu \mathrm{M})$, and the nss-sulfate to nitrate ratio is greater than one. In contrast, the samples analyzed from the warm season (April to September) have typical warm season characteristics: their 36-h air mass back trajectories originate over the ocean (Fig. 1), the volume weighted average nss-sulfate concentration is significantly lower (1.2$4.4 \mu \mathrm{M})$, and the nss-sulfate to nitrate ratio is less than one. The 1 September 2009 sample, which falls near the end of the warm season, has a mix of cold and warm season characteristics (see below).

As discussed above and documented by others (Moody, 1988, 1989, 1995; Galloway et al., 1996; Hastings et al., 2003; Knapp et al., 2010), despite the clear difference in air mass origin and anthropogenic tracers such as nss-sulfate, the nitrate and total reduced nitrogen $\left(\mathrm{NH}_{4}^{+}+\mathrm{WSON}\right)$ concentrations are not statistically different in Bermuda rain from the cold season to the warm season. The isotopic source studies of Hastings et al. (2003) and Knapp et al. (2010) suggest that the nitrate and the total $\mathrm{N}$ have distinct sources from the cold season to the warm season. However, it was uncertain whether the differences in total $\mathrm{N}$ were driven by changes in the WSON pool. The lack of compositional information

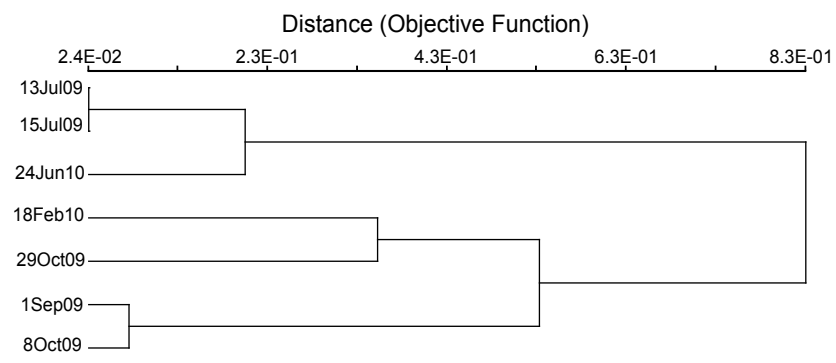

Fig. 5. Linkage diagram of seven rainwater samples including all $\mathrm{m} / \mathrm{z}$ 's detected with peak heights converted to presence/absence. The horizontal distance represents the objective distance function.

on the WSON in marine rain, and the challenge of an isotopic source study on such a complex mixture have hindered similar studies. Thus, we investigate whether the WSON measured in Bermuda rain is consistent in composition and source in the face of changing air mass back-trajectories and regimes.

\subsubsection{Cluster analysis}

The similarity in composition among the seven samples was examined using cluster analysis (Orloci, 1967). The full $\mathrm{m} / \mathrm{z}$ list was used with the peak heights converted to presence/absence. A Bray-Curtis distance matrix was created and then used in conjunction with the Ward's linkage method to produce a distance dendrogram (PC Ord v 5.3). The horizontal axis of the distance dendrogram represents the objective distance function. This analysis takes into account every measured $\mathrm{m} / \mathrm{z}$ at an average of 5000 per sample. A comprehensive comparison of the chemical composition across samples needs to account for all of the detected species, making multivariate statistical tools ideal.

The two July samples collected two days apart are very close in composition, as evidenced by minimal horizontal distance on this scale (Fig. 5). The 1 September 2009 and 8 October 2009 samples are also very closely related in composition; however, there is a measurable distance on the dendrogram for these two samples, indicating that they are not as closely related as the two July samples are to one another. The dendrogram clearly shows two distinct groups that align roughly with the cold and warm seasons, respectively. This clustering based on cold and warm seasons is supported by the $\mathrm{N}$ focused van Krevelen diagrams (Fig. 6). The cold season rainwater has regular patterns that are similar to what was seen for continental rainwater, extending to an $\mathrm{O}: \mathrm{C}$ ratio of one. The warm season $\mathrm{N}$ based van Krevelen appears to have less of a patterned, regular structure, and the dominant clusters extend to an $\mathrm{O}: \mathrm{C}$ of only $\sim 0.5$, indicating less influence from anthropogenic and/or secondary formation processes. The clear clustering by season and the differences in van Krevelen suggest that the full suite of organic compounds that contribute to bulk organic matter concentrations 

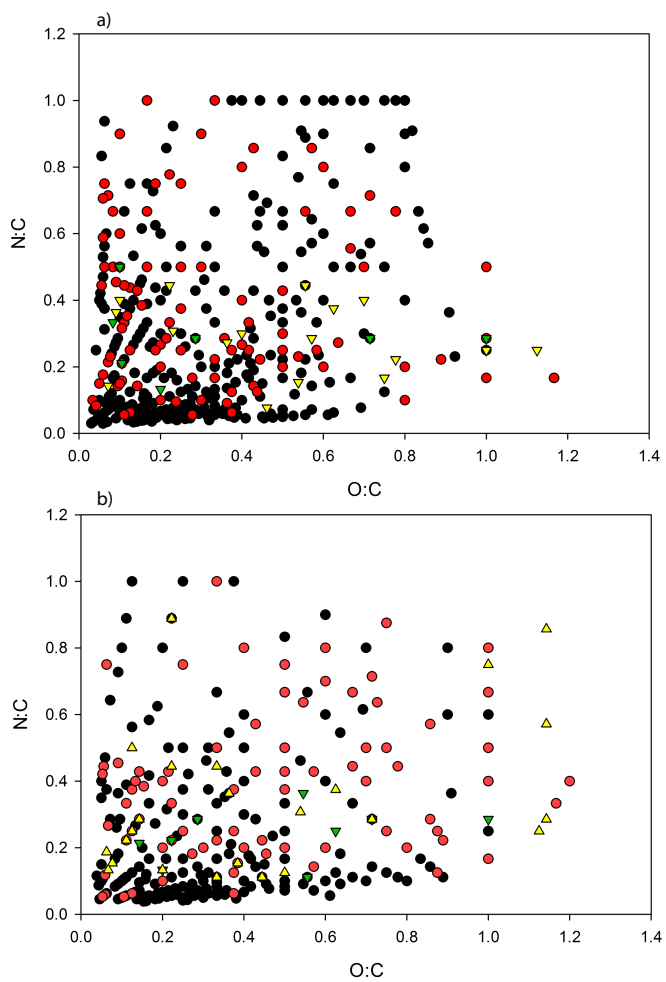

Fig. 6. (a, b) $\mathrm{N}$ focused van Krevelen diagram featuring elemental ratios of all $\mathrm{N}$ containing compounds in (a) warm season 13 July 2009 and (b) cold season 29 October 2009 marine rainwater. Legend denotes the compound class.

is in fact different from the cold season to the warm season, despite the lack of a clear seasonal trend in concentration.

It should be noted that the 1 September 2009, a warm season sample, clusters closely with the 8 October 2009 sample. The 1 September 2009 sample is interesting in that it exhibits both warm and cool season characteristics. The 36-h back trajectory indicates marine air mass origins (Fig. 1a), yet this sample has cold season chemical characteristics, including a high nss-sulfate concentration and a sulfate to nitrate ratio $>1$. We also note that the isotopic composition of nitrate in this sample is typical of a warm season sample based on comparison with Hastings et al. (2003); the $\delta^{15} \mathrm{~N}$ of nitrate is high and the $\delta^{18} \mathrm{O}$ of nitrate is low $\left(\delta^{15} \mathrm{~N}=8.0 \%, \delta^{18} \mathrm{O}=55.9 \%\right.$ ). According to the Bermuda Weather Service, during this time frame, the remnants of Tropical Storm Danny merged with a low pressure system from the northeastern US, which led to moderate showers. This mixing of tropical storm rainwater with a continental influenced system could explain why the 1 September 2009 rainwater has mixed characteristics.

\section{Conclusions and implications}

Amine salts and MSA are the most abundant organic species in marine organic aerosols (Facchini et al., 2008a), which is consistent with the presence of amino acids, the dominance of reduced $\mathrm{N}$ species, and the prevalence of $\mathrm{S}$ containing compounds that we see in the rainwater organic matter. There is clear evidence of marine biological origin for these amine salts, which partition to the aerosol phase by a gas-toparticle conversion process and correlate in space and time with MSA emissions (Sorooshian et al., 2009). The amine salts are likely end products of the photochemical and/or microbial alteration of organic matter in the surface ocean, similar to the oceanic emissions of ammonia, DMS, and other reduced gases. Atmospheric processing of WIOM will lead to WSOM, which in combination with the oxidative degradation of the amine salts and other reduced species from the surface ocean contribute to the complexity of atmospheric marine WSON. In addition to the composition of the precursor compounds emitted from the surface ocean, the oxidant pool available will also influence the final composition of marine organic aerosol. The continental rainwater organic matter shows distinct signs of secondary processing, for example, higher O:C ratios and lower DBE ratios in every compound class when compared to the marine rainwater. This is likely related to the increased anthropogenic oxidant loading in the atmosphere over the continents. In comparison, the atmospheric oxidant budget in unpolluted low- $\mathrm{NO}_{\mathrm{x}}$ conditions is poorly understood (Hosaynali Beygi et al., 2011), and it is likely that halides play a proportionally more important role in the marine atmosphere.

There are a large number of organic S containing compounds in the marine rainwater, however, no nitrooxy organosulfates or organosulfates. The marine biogenic S cycle involving the conversion of DMS to $\mathrm{SO}_{2}$ and MSA is well documented, but it appears to play a role in the marine organic aerosol cycle that has not been documented previously, leading to the formation of additional organosulfur compounds. The role of $\mathrm{P}$ in atmospheric biogeochemical cycles is potentially interesting as $\mathrm{P}$ is considered the ultimate limiting nutrient to the ocean on long time scales (Tyrrell, 1999). The relative importance of $P$ deposition to the surface ocean increases off-shore, away from riverine sources (Benitez-Nelson, 2000). The N:P ratios in atmospheric samples tend to be very high in comparison to oceanic ratios (100:1 vs. 16:1; Knapp et al., 2008) which has led to documented shifts from $\mathrm{N}$ limitation to $\mathrm{P}$ limitation in lake systems (Elser et al., 2009) and suggested shifts in the Northwestern Pacific Ocean (Kim et al., 2011). In aerosol and rain samples collected in New Zealand, Chen et al. (1984) found that organic $\mathrm{P}$ was $58 \%$ of total $\mathrm{P}$, and it correlated well with sodium, suggesting a common oceanic source. The episodic nature of rain events likely lead to brief pulses of $\mathrm{P}$ deposition which could lead to increased biological productivity over short time periods, as has been observed in 
the oligotrophic Mediterranean Sea (Migon and Sandroni, 1999). A recent review (Mahowald et al., 2008) concludes that the global ocean receives $558 \mathrm{Gg}$ total $\mathrm{P}$ per year, and 96.5 Gg phosphate-P per year from atmospheric deposition, suggesting that the contribution from organic $\mathrm{P}$ is $461.5 \mathrm{Gg} \mathrm{P}$ per year. Understanding the sources, composition, and interconversions of marine biogenic $\mathrm{S}$ and $\mathrm{P}$, including their interaction with organics, is a first step in addressing potential ecosystem implications of their deposition.

As expected based on air mass back trajectories, the rainwater samples cluster into two groups, cold and warm season, and the $\mathrm{N}$ based van Krevelen diagrams for cold season WSON share characteristics with continental rainwater while the warm season samples do not (Fig. 6). This is consistent with work based on carbon isotope analysis of submicron marine aerosol in the Northeast Atlantic and the North Pacific. In the Northeast Atlantic, the carbonaceous aerosol was $80 \%$ of biogenic origin (linked to plankton emissions), with only $20 \%$ from terrestrial sources. In contrast, when polluted air masses advected from Europe into the Northeast Atlantic, the aerosol had 30\% marine biogenic, $40 \%$ fossil fuel, and $30 \%$ continental non-fossil fuel sources (Ceburnis et al., 2011). In the North Pacific, the stable carbon isotopes suggested $46-72 \%$ of the total carbon is of marine origin (Miyazaki et al., 2010).

The total amount of organic aerosol naturally in the remote marine boundary layer is not well constrained (Lapina et al., 2011 and others), with estimates ranging from 2.3 to $75 \mathrm{Tg} \mathrm{C} \mathrm{yr}^{-1}$ (Langmann et al., 2008; Spracklen et al., 2008; Gantt et al., 2009). There have been measurements of plumes of organic material in the marine atmosphere exceeding concentrations seen in continental regions (Ovadnevaite et al., 2011), and efforts have been made to link the high concentration of organics in the marine atmosphere to surface ocean biological productivity (O'Dowd et al., 2004). Recently, terrestrially important biogenic VOCs have been measured in the marine atmosphere (e.g., glyoxal; Sinreich et al., 2010) in concentrations that can only be supported by a marine source. It has been suggested that dissolved organic matter photochemistry in the surface ocean is a potential source of some VOCs (Kieber and Mopper, 1987; Zhou and Mopper, 1997). Almost all observations of VOCs are performed over land, although isoprene emissions from the ocean have been reported (Bonsang et al., 1992; Broadgate et al., 1997) and it is accepted that phytoplankton and bacteria in the ocean emit a variety of VOCs comparable to their terrestrial counterparts as byproducts of photosynthesis. When combined with known biogenic S emissions (Andreae, 1990), reduced $\mathrm{N}$ emissions (Johnson et al., 2008), and the large mass of particle surface available, it is not hard to imagine a complex set of chemical and physical parameters controlling both primary and secondary organic aerosol in the marine atmosphere, creating a chemical complexity that rivals or exceeds that of the anthropogenically impacted continental atmosphere. More work is needed to understand the fate of primary marine organics once emitted to the atmosphere, the dominant processing reactions, and the resulting chemical composition. Improving our understanding of the chemical composition of WSON in the marine atmosphere will help elucidate these complex interactions.

\section{Supplementary material related to this article is available online at: http://www.atmos-chem-phys.net/12/ 3557/2012/acp-12-3557-2012-supplement.pdf.}

Acknowledgements. We acknowledge Melissa Soule, Elizabeth Kujawinski, and the funding sources of the WHOI FT-MS Users' Facility (National Science Foundation OCE-0619608 and the Gordon and Betty Moore Foundation). Travel support for K.E.A. to the WHOI FT-MS Facility was provided by the WHOI Director's discretionary funds. This work was supported by NSF ATM-1044997. Post-doctoral research for K.E.A. support was also provided by the NOAA Climate and Global Change Fellowship. We also thank Alistair Marks and Julianne Rosset for sampling support.

Edited by: M. Petters

\section{References}

Aiken, A. C., Decarlo, P. F., Kroll, J. H., Worsnop, D. R., Huffman, J. A., Docherty, K. S., Ulbrich, I. M., Mohr, C., Kimmel, J. R., Sueper, D., Sun, Y., Zhang, Q., Trimborn, A., Northway, M., Ziemann, P. J., Canagaratna, M. R., Onasch, T. B., Alfarra, M. R., Prévôt, A. S. H., Dommen, J., Duplissy, J., Metzger, A., Baltensperger, U., and Jimenez, J. L.: O/C and OM/OC ratios of primary, secondary, and ambient organic aerosols with highresolution time-of-flight aerosol mass spectrometry, Environ. Sci. Technol., 42, 4478-4485, doi:10.1021/es703009q, 2008.

Altieri, K. E., Turpin, B. J., and Seitzinger, S. P.: Oligomers, organosulfates, and nitrooxy organosulfates in rainwater identified by ultra-high resolution electrospray ionization FTICR mass spectrometry, Atmos. Chem. Phys., 9, 2533-2542, doi:10.5194/acp-9-2533-2009, 2009a.

Altieri, K. E., Turpin, B. J., and Seitzinger, S. P.: Composition of Dissolved Organic Nitrogen in Continental Precipitation Investigated by Ultra-High Resolution FT-ICR Mass Spectrometry, Environ. Sci. Technol., 43, 6950-6955, doi:10.1021/es9007849, 2009b.

Andreae, M. O.: Ocean-atmosphere interactions in the global biogeochemical sulfur cycle, Marine Chem., 30, 1-29, 1990.

Bateman, A. P., Walser, M. L., Desyaterik, Y., Laskin, J., Laskin, A., and Nizkorodov, S. A.: The effect of solvent on the analysis of secondary organic aerosol using electrospray ionization mass spectrometry, Environ. Sci. Technol., 42, 7341-7346, 2008.

Bateman, A. P., Nizkorodov, S. A., Laskin, J., and Laskin, A.: Photolytic processing of secondary organic aerosols dissolved in cloud droplets, Phys. Chem. Chem. Phys., 13, 12199-12212, 2011.

Benitez-Nelson, C. R.: The biogeochemical cycling of phosphorus in marine systems, Earth Sci. Rev., 51, 109-135, 2000. 
Bonsang, B., Polle, C., and Lambert, G.: Evidence for marine production of isoprene, Geophys. Res. Lett., 19, 1129-1132, doi:10.1029/92gl00083, 1992.

Broadgate, W. J., Liss, P. S., and Penkett, S. A.: Seasonal emissions of isoprene and other reactive hydrocarbon gases from the ocean, Geophys. Res. Lett., 24, 2675-2678, doi:10.1029/97g102736, 1997.

Bzdek, B. R., Ridge, D. P., and Johnston, M. V.: Amine exchange into ammonium bisulfate and ammonium nitrate nuclei, Atmos. Chem. Phys., 10, 3495-3503, doi:10.5194/acp-10-3495-2010, 2010a.

Bzdek, B. R., Ridge, D. P., and Johnston, M. V.: Size-dependent reactions of ammonium bisulfate clusters with dimethylamine, J. Phys. Chem., 114, 11638-1644, 2010b.

Ceburnis, D., Garbaras, A., Szidat, S., Rinaldi, M., Fahrni, S., Perron, N., Wacker, L., Leinert, S., Remeikis, V., Facchini, M. C., Prévôt, A. S. H., Jennings, S. G., Ramonet, M., and O'Dowd, C. D.: Quantification of the carbonaceous matter origin in submicron marine aerosol by $13 \mathrm{C}$ and $14 \mathrm{C}$ isotope analysis, Atmos. Chem. Phys., 11, 8593-8606, doi:10.5194/acp-11-8593-2011, 2011.

Claeys, M., Wang, W., Vermeylen, R., Kourtchev, I., Chi, X., Farhat, Y., Surratt, J. D., Gómez-González, Y., Sciare, J., and Maenhaut, W.: Chemical characterisation of marine aerosol at Amsterdam Island during the austral summer of 2006-2007, J. Aerosol Sci., 41, 13-22, 2010.

Cornell, S., Rendell, A., and Jickells, T.: Atmospheric Inputs of Dissolved Organic Nitrogen to the Oceans, Nature, 376, 243246, 1995.

Cornell, S., Mace, K., Coeppicus, S., Duce, R., Huebert, B., Jickells, T., and Zhuang, L. Z.: Organic nitrogen in Hawaiian rain and aerosol, Journal of Geophys. Res.-Atmos., 106, 7973-7983, 2001.

Cornell, S. E., Jickells, T. D., and Thornton, C. A.: Urea in rainwater and atmospheric aerosol, Atmos. Environ., 32, 1903-1910, 1998.

Cornell, S. E., Jickells, T. D., Cape, J. N., Rowland, A. P., and Duce, R. A.: Organic nitrogen deposition on land and coastal environments: a review of methods and data, Atmos. Environ., 37, 2173-2191, 2003.

De Haan, D. O., Hawkins, L. N., Kononenko, J. A., Turley, J. J., Corrigan, A. L., Tolbert, M. A., and Jimenez, J. L.: Formation of Nitrogen-Containing Oligomers by Methylglyoxal and Amines in Simulated Evaporating Cloud Droplets, Environ. Sci. Technol., 45, 984-991, 2011.

Duce, R. A., LaRoche, J., Altieri, K., Arrigo, K. R., Baker, A. R., Capone, D. G., Cornell, S., Dentener, F., Galloway, J., Ganeshram, R. S., Geider, R. J., Jickells, T., Kuypers, M. M., Langlois, R., Liss, P. S., Liu, S. M., Middelburg, J. J., Moore, C. M., Nickovic, S., Oschlies, A., Pedersen, T., Prospero, J., Schlitzer, R., Seitzinger, S., Sorensen, L. L., Uematsu, M., U1loa, O., Voss, M., Ward, B., and Zamora, L.: Impacts of atmospheric anthropogenic nitrogen on the open ocean, Science, 320, 893-897, doi:10.1126/science.1150369, ISSN 0036-8075, 2008.

Elser, J. J., Andersen, T., Baron, J. S., Bergstrom, A.-K., Jansson, M., Kyle, M., Nydick, K. R., Steger, L., and Hessen, D. O.: Shifts in Lake N:P Stoichiometry and Nutrient Limitation Driven by Atmospheric Nitrogen Deposition, Science, 326, 835837, doi:10.1126/science.1176199, 2009.
Ervens, B., Volkamer, R.: Glyoxal processing by aerosol multiphase chemistry: Towards a kinetic modeling framework of secondary organic aerosol formation in aqueous particles, Atmos. Chem. Phys., 10, 8219-8244, doi:10.5194/acp-10-8219-2010, 2010.

Facchini, M. C., Decesari, S., Rinaldi, M., Carbone, C., Finessi, E., Mircea, M., Fuzzi, S., Moretti, F., Tagliavini, E., Ceburnis, D., and O'Dowd, C. D.: Important Source of Marine Secondary Organic Aerosol from Biogenic Amines, Environ. Sci. Technol., 42, 9116-9121, doi:10.1021/es8018385, 2008a.

Facchini, M. C., Rinaldi, M., Decesari, S., Carbone, C., Finessi, E., Mircea, M., Fuzzi, S., Ceburnis, D., Flanagan, R., Nilsson, E. D., de Leeuw, G., Martino, M., Woeltjen, J., and O'Dowd, C. D.: Primary submicron marine aerosol dominated by insoluble organic colloids and aggregates, Geophys. Res. Lett., 35, L17814, doi:10.1029/2008g1034210, 2008b.

Galloway, J. N., Likens, G. E., Keene, W. C., and Miller, J. M.: The composition of precipitation in remote areas of the World, J. Geophys. Res.-Ocean. Atmos., 87, 8771-8786, 1982.

Galloway, J. N., Howarth, R. W., Michaels, A. F., Nixon, S. W., Prospero, J. M., and Dentener, F. J.: Nitrogen and phosphorus budgets of the North Atlantic Ocean and its watershed, Biogeochemistry, 35, 3-25, 1996.

Galloway, J. N., Dentener, F. J., Capone, D. G., Boyer, E. W., Howarth, R. W., Seitzinger, S. P., Asner, G. P., Cleveland, C. C., Green, P. A., Holland, E. A., Karl, D. M., Michaels, A. F., Porter, J. H., Townsend, A. R., and Vorosmarty, C. J.: Nitrogen cycles: past, present, and future, Biogeochemistry, 70, 153-226, 2004.

Gantt, B., Meskhidze, N., and Kamykowski, D.: A new physically-based quantification of marine isoprene and primary organic aerosol emissions, Atmos. Chem. Phys., 9, 4915-4927, doi:10.5194/acp-9-4915-2009, 2009.

Gomez-Gonzalez, Y., Surratt, J. D., Cuyckens, F., Szmigielski, R., Vermeylen, R., Jaoui, M., Lewandowski, M., Offenberg, J. H., Kleindienst, T. E., Edney, E. O., Blockhuys, F., Van Alsenoy, C., Maenhaut, W., and Claeys, M.: Characterization of organosulfates from the photooxidation of isoprene and unsaturated fatty acids in ambient aerosol using liquid chromatography/(-) electrospray ionization mass spectrometry, J. Mass Spectrom., 43, 371-382, doi:10.1002/jms.1329, ISSN 1076-5174, 2008.

Gorzelska, K., Galloway, J. N., Watterson, K., and Keene, W. C.: Water-soluble primary amine compounds in rural continental precipitation, Atmos. Environ., 26A, 1005-1018, 1992.

Graham, W. F. and Duce, R. A.: Atmospheric pathways of the phosphorus cycle, Geocheim. Cosmochim. Acta, 43, 1195-1208, 1979.

Gruber, N. and Sarmiento, J. L.: Global patterns of marine nitrogen fixation and denitrification, Global Biogeochem. Cy., 11, 235266, 1997.

Haan, D. O. D., Corrigan, A. L., Smith, K. W., Stroik, D. R., Turley, J. J., Lee, F. E., Tolbert, M. A., Jimenez, J. L., Cordova, K. E., and Ferrell, G. R.: Secondary organic aerosol-forming reactions of glyoxal with amino acids, Environ. Sci. Technol., 43, 28182824, 2009.

Hastings, M. G., Sigman, D. M., and Lipschultz, F.: Isotopic evidence for source changes of nitrate in rain at Bermuda, J. Geophys. Res.-Atmos., 108, 4790, doi:10.1029/2003jd003789, ISSN 0148-0227, 2003. 
Hawkins, L. N. and Russell, L. M.: Polysaccharides, proteins, and phytoplankton fragments: four chemically distinct types of marine primary organic aerosol classified by single particle spectromicroscopy, Adv. Meteorol., 2010, 612132, 14 pp., 2010.

Hawkins, L. N., Russell, L. M., Covert, D. S., Quinn, P. K., and Bates, T. S.: Carboxylic acids, sulfates, and organosulfates in processed continental organic aerosol over the southeast Pacific Ocean during VOCALS-REx 2008, J. Geophys. Res.-Atmos., 115, D13201, doi:10.1029/2009jd013276, 2010.

Hosaynali Beygi, Z., Fischer, H., Harder, H. D., Martinez, M., Sander, R., Williams, J., Brookes, D. M., Monks, P. S., and Lelieveld, J.: Oxidation photochemistry in the Southern Atlantic boundary layer: unexpected deviations of photochemical steady state, Atmos. Chem. Phys., 11, 8497-8513, doi:10.5194/acp-118497-2011, 2011.

Howarth, R. W., Swaney, D. P., Butler, T. J., and Marino, R.: Climatic control on eutrophication of the Hudson River estuary, Ecosystems, 3, 210-215, 2000.

Hughey, C. A., Hendrickson, C. L., Rodgers, R. P., and Marshall, A. G.: Kendrick mass defect spectrum: A compact visual analysis for ultrahigh-resolution broadband mass spectra, Anal. Chem., 73, 4676-4681, doi:10.1021/ac010560w, 2001.

Jickells, T., Knap, A., Church, T., Galloway, J., and Miller, J.: ACID-RAIN ON BERMUDA, Nature, 297, 55-57, 1982.

Johnson, M. T., Liss, P. S., Bell, T. G., Lesworth, T. J., Baker, A. R., Hind, A. J., Jickells, T. D., Biswas, K. F., Woodward, E. M. S., and Gibb, S. W.: Field observations of the ocean-atmosphere exchange of ammonia: Fundamental importance of temperature as revealed by a comparison of high and low latitudes, Global Biogeochem. Cy., 22, GB1019, doi:10.1029/2007GB003039, 2008.

Keene, W. C., Pszenny, A. A. P., Galloway, J. N., and Hawley, M. E.: Sea-Salt Corrections and Interpretation of Constituent Ratios in Marine Precipitation, J. Geophys. Res., 91, 6647-6658, doi:10.1029/JD091ID06P06647, 1986.

Keene, W. C., Maring, H., Maben, J. R., Kieber, D. J., Pszenny, A. A. P., Dahl, E. E., Izaguirre, M. A., Davis, A. J., Long, M. S., and Zhou, X.: Chemical and physical characteristics of nascent aerosols produced by bursting bubbles at a model air-sea interface, J. Geophys. Res., 112, D21202, doi:10.1029/2007JD008464, 2007.

Kieber, D. J. and Mopper, K.: Photochemical formation of glyoxylic and pyruvic acids in seawater, Mar. Chem., 21, 135-149, 1987.

Kim, T.-W., Lee, K., Najjar, R. G., Jeong, H.-D., and Jeong, H. J.: Increasing $\mathrm{N}$ Abundance in the Northwestern Pacific Ocean Due to Atmospheric Nitrogen Deposition, Science, 334, 505509, doi:10.1126/science.1206583, 2011.

Knapp, A. N., Sigman, D. M., and Lipschultz, F.: N isotopic composition of dissolved organic nitrogen and nitrate at the Bermuda Atlantic time-series study site, Global Biogeochem. Cy., 19, GB1018, doi:10.1029/2004GB002320, 2005.

Knapp, A. N., DiFiore, P. J., Deutsch, C., Sigman, D. M., and Lipschultz, F.: Nitrate isotopic composition between Bermuda and Puerto Rico: Implications for N-2 fixation in the Atlantic Ocean, Global Biogeochem. Cy., 22, GB3014, doi:10.1029/2007GB003107, 2008.

Knapp, A. N., Hastings, M. G., Sigman, D. M., Lipschultz, F., and Galloway, J. N.: The flux and isotopic composition of reduced and total nitrogen in Bermuda rain, Marine Chem., 120, 83-89,
2010.

Koch, B. P., Witt, M. R., Engbrodt, R., Dittmar, T., and Kattner, G.: Molecular formulae of marine and terrigenous dissolved organic matter detected by electrospray ionization Fourier transform ion cyclotron resonance mass spectrometry, Geochim. Cosmochim. Acta, 69, 3299-3308, 2005.

Kodama, T., Furuya, K., Hashihama, F., Takeda, S., and Kanda, J.: Occurrence of rain-origin nitrate patches at the nutrient-depleted surface in the East China Sea and the Philippine Sea during summer, J. Geophys. Res., 116, C08003, doi:10.1029/2010JC006814, 2011.

Kujawinski, E. B. and Behn, M. D.: Automated analysis of electrospray ionization Fourier transform ion cyclotron resonance mass spectra of natural organic matter, Analyt. Chem., 78, 4363-4373, 2006.

Kujawinski, E. B., Longnecker, K., Blough, N. V., Vecchio, R. D., Finlay, L., Kitner, J. B., and Giovannoni, S. J.: Identification of possible source markers in marine dissolved organic matter using ultrahigh resolution mass spectrometry, Geochim. Cosmochim. Acta, 73, 4384-4399, 2009.

Langmann, B., Scannell, C., and O'Dowd, C.: New Directions: Organic matter contribution to marine aerosols and cloud condensation nuclei, Atmos. Environ., 42, 7821-7822, 2008.

Lapina, K., Heald, C. L., Spracklen, D. V., Arnold, S. R., Allan, J. D., Coe, H., McFiggans, G., Zorn, S. R., Drewnick, F., Bates, T. S., Hawkins, L. N., Russell, L. M., Smirnov, A., O'Dowd, C. D., and Hind, A. J.: Investigating organic aerosol loading in the remote marine environment, Atmos. Chem. Phys., 11, 88478860, doi:10.5194/acp-11-8847-2011, 2011.

Laskin, A., Smith, J. S., and Laskin, J.: Molecular characterization of nitrogen-containing organic compounds in biomass burning aerosols using high-resolution mass spectrometry, Environ. Sci. Technol., 43, 3764-3771, doi:10.1021/es803456n, 2009.

Mace, K. A., Artaxo, P., and Duce, R. A.: Water-soluble organic nitrogen in Amazon Basin aerosols during the dry (biomass burning) and wet seasons, J. Geophys. Res.-Atmos., 108, 4512, doi:10.1029/2003JD003557, 2003a.

Mace, K. A., Duce, R. A., and Tindale, N. W.: Organic nitrogen in rain and aerosol at Cape Grim, Tasmania, Australia, J. Geophys. Res.-Atmos., 108, 4338, doi:10.1029/2002JD003051, $2003 \mathrm{~b}$.

Mace, K. A., Kubilay, N., and Duce, R. A.: Organic nitrogen in rain and aerosol in the eastern Mediterranean atmosphere: An association with atmospheric dust, J. Geophys. Res.-Atmos., 108, 4320, doi:10.1029/2002JD002997, 2003c.

Mahowald, N., Jickells, T. D., Baker, A. R., Artaxo, P., BenitezNelson, C. R., Bergametti, G., Bond, T. C., Chen, Y., Cohen, D. D., Herut, B., Kubilay, N., Losno, R., Luo, C., Maenhaut, W., McGee, K. A., Okin, G. S., Siefert, R. L., and Tsukuda, S.: Global distribution of atmospheric phosphorus sources, concentrations and deposition rates, and anthropogenic impacts, Global Biogeochem. Cy., 22, GB4026, doi:10.1029/2008gb003240, 2008.

Mandalakis, M., Apostolaki, M., Tziaras, T., Polymenakou, P., and Stephanou, E. G.: Free and combined amino acids in marine background atmospheric aerosols over the Eastern Mediterranean, Atmos. Environ., 45, 1003-1009, 2010.

Mantini, D., Petrucci, F., Pieragostino, D., Del Boccio, P., Di Nicola, M., Di Ilio, C., Federici, G., Sacchetta, P., Comani, S., and Urbani, A.: LIMPIC: a computational method for the sep- 
aration of protein MALDI-TOF-MS signals from noise, BMC Bioinformatics, 8, 101, 2007.

McGregor, K. G. and Anastasio, C.: Chemistry of fog waters in California's Central Valley: 2. Photochemical transformations of amino acids and alkyl amines, Atmos. Environ., 35, 1091-1104, 2001.

McLafferty, F. W. and Turecek, F.: Interpretation of Mass Spectra, 4 ed., University Science Books, Mill Valley, CA, USA, 1993.

Migon, C. and Sandroni, V.: Phosphorus in Rainwater: Partitioning Inputs and Impact on the Surface Coastal Ocean, Limnol. Oceanogr., 44, 1160-1165, 1999.

Miyazaki, Y., Kawamura, K., and Sawano, M.: Size distributions of organic nitrogen and carbon in remote marine aerosols: Evidence of marine biological origin based on their isotopic ratios, Geophys. Res. Lett., 37, L06803, doi:10.1029/2010g1042483, 2010.

Moody, J. L. and Galloway, J. N.: Quantifying the relationship between the atmospheric transport and the chemical composition of precipitation on Bermuda, Tellus, 40B, 463-479, 1988.

Moody, J. L., Galusky, J. A., and Galloway, J. N.: The use of atmospheric transport pattern recognition techniques in understanding variation in precipitation chemistry, Proceedings of the Baltimore Symposium, May 1989, IAHS Publ. No. 179, 1989.

Moody, J. L., Oltmans, S. J., Levy, H., and Merrill, J. T.: A transport climatology of tropospheric ozone, Bermuda: 1988-1991, J, Geophys. Res.-Ocean. Atmos., 100, 7179-7194, 1995.

Mopper, K. and Zimmermann, F.: Free amino acids in marine rains: evidence for oxidation and potential role in nitrogen cycling, Nature, 325, 246-249, 1987.

Nguyen, T. B., Laskin, J., Laskin, A., and Nizkorodov, S. A.: Nitrogen-containing Organic Compounds and Oligomers in Secondary Organic Aerosol Formed by Photooxidation of Isoprene, Environ. Sci. Technol., 45, 6908-6918, 2011.

Nozière, B. and Córdova, A.: A kinetic and mechanistic study of the amino acid catalyzed aldol condensation of acetaldehyde in aqueous and salt solutions, J. Phys. Chem. A, 112, 2827-2837, 2008.

O’Dowd, C. D., Facchini, M. C., Cavalli, F., Ceburnis, D., Mircea, M., Decesari, S., Fuzzi, S., Yoon, Y. J., and Putaud, J. P.: Biogenically driven organic contribution to marine aerosol, Nature, 431, 676-680, 2004.

Orloci, L.: An agglomerative method for classification of plant communities, J. Ecol., 55, 193-206, 1967.

Ovadnevaite, J., O'Dowd, C., Dall'Osto, M., Ceburnis, D., Worsnop, D. R., and Berresheim, H.: Detecting high contributions of primary organic matter to marine aerosol: A case study, Geophys. Res. Lett., 38, L02807, doi:10.1029/2010g1046083, 2011.

Paerl, H. W., Rudek, J., and Mallin, M. A.: Stimulation of phytoplankton production in coastal waters by natural rainfall inputs: Nutritional and trophic implications, Marine Biol., 107, 247254, 1990.

Paerl, H. W., Willey, J. D., Go, M., Peierls, B. L., Pinckney, J. L., and Fogel, M. L.: Rainfall stimulation of primary production in western Atlantic Ocean waters: roles of different nitrogen sources and co-limiting nutrients, Marine Ecol.-Prog. Ser., 176, 205-214, 1999.

Paerl, H. W., Dennis, R. L., and Whitall, D. R.: Atmospheric deposition of nitrogen: Implications for nutrient over-enrichment of coastal waters, Estuaries, 25, 677-693, 2002.
Peierls, B. L. and Paerl, H. W.: Bioavailability of atmospheric organic nitrogen deposition to coastal phytoplankton, Limnol. Oceanogr., 42, 1819-1823, 1997.

Qiu, C., Wang, L., Lal, V., Khalizov, A. F., and Zhang, R.: Heterogeneous Reactions of Alkylamines with Ammonium Sulfate and Ammonium Bisulfate, Environ. Sci. Technol., 45, 4748-4755, 2011.

Seitzinger, S. P., Styles, R. M., Lauck, R., and Mazurek, M. A.: Atmospheric pressure mass spectrometry: A new analytical chemical characterization method for dissolved organic matter in rainwater, Environ. Sci. Technol., 37, 131-137, 2003.

Sinreich, R., Coburn, S., Dix, B., and Volkamer, R.: Ship-based detection of glyoxal over the remote tropical Pacific Ocean, Atmos. Chem. Phys., 10, 11359-11371, doi:10.5194/acp-1011359-2010, 2010.

Sorooshian, A., Padró, L. T., Nenes, A., Feingold, G., McComiskey, A., Hersey, S. P., Gates, H., Jonsson, H. H., Miller, S. D., and Stephens, G. L.: On the link between ocean biota emissions, aerosol, and maritime clouds: Airborne, ground, and satellite measurements off the coast of California, Global Biogeochem. Cy., 23, GB4007, doi:10.1029/2009GB003464, 2009.

Southam, A. D., Payne, T. G., Cooper, H. J., Arvanitis, T. N., and Viant, M. R.: Dynamic range and mass accuracy of widescan direct infusion nanoelectrospray Fourier Transform Ion Cyclotron Resonance mass spectrometry-based metabolomics increased by the spectral stitching method, Anal. Chem., 79, 45954602, 2007.

Spokes, L. J., Yeatman, S. G., Cornell, S. E., and Jickells, T. D.: Nitrogen deposition to the eastern Atlantic Ocean. The importance of south-easterly flow, Tellus Series B-Chem. Phys. Meteorol., 52, 37-49, 2000.

Spracklen, D. V., Arnold, S. R., Sciare, J., Carslaw, K. S., and Pio, C.: Globally significant oceanic source of organic carbon aerosol, Geophys. Res. Lett., 35, L12811, doi:10.1029/2008g1033359, 2008.

Surratt, J. D., Kroll, J. H., Kleindienst, T. E., Edney, E. O., Claeys, M., Sorooshian, A., Ng, N. L., Offenberg, J. H., Lewandowski, M., Jaoui, M., Flagan, R. C., and Seinfeld, J. H.: Evidence for organosulfates in secondary organic aerosol, Environ. Sci. Technol., 41, 517-527, 2007.

Surratt, J. D., Gomez-Gonzalez, Y., Chan, A. W. H., Vermeylen, R., Shahgholi, M., Kleindienst, T. E., Edney, E. O., Offenberg, J. H., Lewandowski, M., Jaoui, M., Maenhaut, W., Claeys, M., Flagan, R. C., and Seinfeld, J. H.: Organosulfate Formation in Biogenic Secondary Organic Aerosol, J. Phys. Chem. A, 112, 8345-8378, 2008.

Tohno, S., Kawai, J., Kitajima, Y.: Identification of the chemical states of phosphorus in atmospheric aerosols by XANES spectrometry, J. Synchrotr. Rad., 8, 958-960, 2001.

Tyrrell, T.: The relative influences of nitrogen and phosphorus on oceanic primary production, Nature, 400, 525-531, 1999.

Vetter Russell, D., Matrai Patricia, A., Javor, B., and O'Brien, J.: Reduced Sulfur Compounds in the Marine Environment, in: Biogenic Sulfur in the Environment, ACS Symposium Series, 393, American Chemical Society, Washington, DC, USA, 243-261, 1989.

Vitousek, P. M., Aber, J. D., Howarth, R. W., Likens, G. E., Matson, P. A., Schindler, D. W., Schlesinger, W. H., and Tilman, D. G.: Human alteration of the global nitrogen cycle: Sources and 
consequences, Ecological Applications, 7, 737-750, 1997.

Volkamer, R., Jimenez, J. L., San Martini, F., Dzepina, K., Zhang, Q., Salcedo, D., Molina, L. T., Worsnop, D. R., Molina, M. J.: Secondary organic aerosol formation from anthropogenic air pollution: Rapid and higher than expected, Geophys. Res. Lett., 33, L17811, doi:10.1029/2006GL026899, 2006.

Wang, L., Lal, V., Khalizov, A. F., and Zhang, R.: Heterogeneous Chemistry of Alkylamines with Sulfuric Acid: Implications for Atmospheric Formation of Alkylaminium Sulfates, Environ. Sci. Technol., 44, 2461-2465, doi:10.1021/es9036868, 2010.

Wedyan, M. A. and Preston, M. R.: The coupling of surface seawater organic nitrogen and the marine aerosol as inferred from enantiomer-specific amino acid analysis, Atmos. Environ., 42, 8698-7705, doi:10.1016/j.atmosenv.2008.04.038, 2008.

Yu, G., Bayer, A. R., Galloway, M. M., Korshavn, K. J., Fry, C. G., and Keutsch, F. N.: Glyoxal in Aqueous Ammonium Sulfate Solutions: Products, Kinetics and Hydration Effects, Environ. Sci. Technol., 45, 6336-6342, 2011.
Zhang, Q., Anastasio, C., and Jimemez-Cruz, M.: Water-soluble organic nitrogen in atmospheric fine particles (PM2.5) from northern California, J. Geophys. Res.-Atmos., 107, 4112, doi:10.1029/2001JD000870, 2002.

Zhang, Y., Zheng, L. X., Liu, X. J., Jickells, T., Cape, J. N., Goulding, K., Fangmeier, A., and Zhang, F. S.: Evidence for organic N deposition and its anthropogenic sources in China, Atmos. Environ., 42, 1035-1041, doi:10.1016/j.atmosenv.2007.12.015|ISSN 1352-2310, 2008.

Zhou, X. and Mopper, K.: Photochemical production of lowmolecular-weight carbonyl compounds in seawater and surface microlayer and their air-sea exchange, Mar. Chem., 56, 201-213, 1997. 